\title{
Aberration of Cultures: A Study of Distortion of Akan Cultures in Kumawood Movies in Ghana
}

\author{
Kquofi, Steve (PhD) \\ Department of General Art Studies, Faculty of Art \\ Kwame Nkrumah University of Science and Technology, Kumasi, Ghana \\ Croffie, Godfred Kojo (PhD) \\ Department of General Art Studies, Faculty of Art \\ Kwame Nkrumah University of Science and Technology, Kumasi, Ghana \\ *Corresponding Author: Kquofi, Steve (PhD), Department of General Art Studies, Faculty of Art \\ Kwame Nkrumah University of Science and Technology, Kumasi, Ghana
}

Received Date: 14-06-2017

Accepted Date: 23-06-2017

Published Date: 28-06-2017

\begin{abstract}
Kumawood movies are very popular in Ghana now with the decline of films produced in the English language, which patrons have tagged 'Glamour' films, to show contrast to those produced in Kumasi to satisfy the 'film taste' of the masses, which mostly are disconnected from the 'Glamour' films. Despite their popularity because of their production in the local language, Akan Twi, these movies aberrate Ghanaian cultures, especially the arts, customs, lifestyles, background, and habits that characterize the traditional Akan society, which the movies largely portray. Based on qualitative research approach, six Kumawood movies were selected for critical review. The study sought to ascertain how Kumawood movies presented the cultural values of the people. The results indicated that Kumawood movies showcased diverse Akan cultural elements such as proverbs used for ensuring positive moral conducts, welfare, and acquisition of wisdom; rich traditional body adornments; Akan traditional festivals, folksongs, drumming and dancing, games; as well as sense of communal welfare, hospitality and traditional courtesies. However, these rich traditional cultural values of the people were largely distorted with foreign cultural elements such as Western banquet-like hall decorations, Hip-pop music, and mode of dressing, public romantic scenes, continental food and many others. These distortions have implications on the preservation, conservation and perpetuation of the rich Ghanaian cultural heritage for sustainable development.
\end{abstract}

Keywords: Cultural elements, distortion, Ghanaian cultures, Kumawood movies, proverbs.

\section{INTRODUCTION}

Movies are cultural artifacts created by specific cultures, which reflect those cultures, articulate social consciousness and in turn affect them (Ogunleye, 2014; Ugbam et al., 2014; Crane, 2014). However, African films remain "foreigners in their own countries" where the makers of popular movies have never been principally concerned with authenticity, cultural revival, or cultural preservation (Garritano, 2008). Implicit of these phenomena is for African filmmakers to intensify efforts in exploiting their own cultural resources, rather than importing the "valueless" aspects of some "foreign" cultures. As argued by Ugbam et al. (2014), "to lose one's culture is tantamount to losing one's identity" and "a society cut off from its roots may thrive for a while on its own momentum but eventually it will wither like flowers cut in a vase" (Ugbam et al., 2014).

Undoubtedly, films are important art forms, a source of popular entertainment and a powerful method for educating and or indoctrinating citizens of which its visual elements in motion pictures serve as a universal power of communication (Ogunleye, 2014). Ryan (2009) notes the important roles films play in the transmission of culture by indicating that films are both culturally rich and complex; and constitute a form of entertainment that reflects daily lives, which often emphasizes on romance, humor and violent elements as well as fantasies, dreams and imagination through which individuals escape from the realities of daily 
existence. In his view, the fact that governments spend large sums to maintain a presence in the film industry indicates that films are perceived as having considerable symbolic and cultural values.

Ultimately, there has been a long-standing concern since the last four decades as to what form African films should look like in order to be different from Western cinema. The African major conferences on cultural industries notably, the Federation of African filmmakers (FEPACI) in Algiers in 1975, emphasised this commitment to this development, that African films should represent Africa from an African point of view. It also advocated for the rejection of the commercial and the Western film codes. The Dakar Plan of Action on Cultural Industries in 1992 and Plan of Action for Cultural and Creative Industries in October 2008 by African Union Ministers of Culture recognized further the potential role of cultural industries in driving economic and social development of the continent (Kwanashie et al., 2009). Conversely, many African directors have retreated somewhat from such radical calls over the past two decades, worrying far more about the problems of forging a popular African cinema and creating a viable African film industry and in trying to position the African cinema in the global scene.

\section{Movie or Film Concept}

Conceptually, movie or film denotes a work of art on celluloid (from the evolution of the motion picture) and (in modern times) on video and now digital single lens reflex (DSLR) formats. Film, as a communicative medium, has till date been used to entertain, instruct, subjugate, persuade and propagate the overall social, political, economic and educational needs of the inhabitants of the contemporary world that are deeply dependent on communication in its various forms, including film as a mass medium (Akashoro, 2010). Film is, therefore, considered to be an important art form, a source of popular entertainment and a powerful method for educating or indoctrinating citizens.

\section{Cultural Aspects of Movies}

Movie in a broader sense falls under culture, which defines the holistic content and identity of what is showcased for viewers' appreciation. Culture here, is generally the arts and other manifestations of human intellectual activities and achievements regarded collectively, with elements such as ideas, customs, legends, folktales, traditional stories, etc. and social behaviour of a particular people or society. Each time the word 'culture' is mentioned, the first thing that comes to mind is a people's way of life. Many sociologists and historians define culture as the complex whole of man's acquisitions of knowledge, morals, beliefs, arts, customs, technology and values which are transmitted from generation to generation (Amayo et al, 2012). As a concept, Amayo et al. agree with Anyanwu (2011) that, when viewed from a broader perspective, culture could be "perceived as a way of life, which encompasses all human efforts, achievements and attitudes". Also, culture manifests in religion, language, philosophy, music, dance, drama, architecture, political organization, technology, education, values, knowledge system, social system, judicial or legal organization, and morality. Culture therefore constitutes "what is natural" in the understanding of the tradition of a people (Nwala, 1985).

In a similar view, Oni (2005) and Ogechukwu et al. (2014) all contend that the concept of culture consists of the values the members of a given group hold, the norms they follow, and the material goods they create. Adeleke (2003) argues that virtually all these varied definitions of 'culture' would seem to anchor on anthropological definition given by Tylor (1871). According to him, culture is that complex whole which includes knowledge, brief, law, art, morals, customs and any other capabilities and habits acquired by man as a member of a society. Adeleke further posits that culture is both 'shared' and 'learnt' in a community or a given linguistic group; points out that in essence, culture is a communal property as it reflects the being of an individual in its totality. In the light of all the attempts to define culture, it is obvious that movies (films) produced by any group of people should be an embodiment of the characteristics, beliefs, values, symbols and every aspects of the people's culture.

\section{The Akan People and Their Language}

The Akans belong to the Kwa group of languages found in West Africa. The Akan language is the indigenous language with the largest number of speakers in Ghana. About $49.1 \%$ of the national population of Ghana is Akan, based on the Ghana National 2010 Census. Akan has the largest percentages of both Legislative Instrument 1 and Legislative Instrument 2 speakers in Ghana. According to Gedzi (2014), the Akan comprise sub-ethnic groups such as Akwamu, Guan, Fante, Denkyira, 
Brong, Akyem, Kwahu, Sefwi, Wassa, Akwapim, Assin and Asante. Geographically, the Akan occupy the Western, Central and Ashanti regions, as well as parts of the Brong-Ahafo, Eastern regions of Ghana and the eastern part of the Cote D'Ivoire. There is consensus based on research that Akan groups, migrated from ancient Mesopotamia to sub-Saharan Africa.

\section{Movies in Akan Language}

"Akan" language films or movies tell the everyday life of the Ghanaian, particularly in Kumasi. Kumasi Yonkor, for example, is a Twi language movie hailed for depicting the daily struggles of the low income Ghanaians who live in 'compound houses'. The story lines easily resonate with the audiences, compared with some of the movies in English, which have been criticized for telling stories that do not tell the Ghanaian story. The Akan (Twi) language is the largest spoken language in Ghana (Yamoah, 2014), spoken by about $44 \%$ of Ghanaians (Ghana Statistical Service, 2012).

The surge of films in the Akan language has created a niche, adopting the production strategies by some production groups such as 'Kumawood' (films produced using the Akan language, regardless of where they were produced in Ghana). Therefore, "Akan" Films are also known as Kumawood films. Kumawood films are very popular in Ghana now, with the decline of films produced in the English language, which patrons have tagged 'Glamour' films, to show contrast to those produced in Kumasi to satisfy the 'film taste' of the masses, which mostly are disconnected from the 'Glamour' films (Yamoah, 2014). The dominance of the Akan video film industry in Ghana like the Kumawood, is suppressing the dominance of Ghanaian films in English and the Nollywood (Nigerian) films marketed and distributed in Ghana. Currently, of the ten movies released in Ghana weekly, seven are from Kumawood. The Kumawood shows two main categories of filmmaking namely, the "Twi" and the "Twinglish" movies. The Twi movies are the type of films where the lingua franca is Asante Twi and other Akan languages, whereas the Twinglish movies are the types of films where the lingua franca is a combination of English language and the other Akan languages. Nationally, Ghallywood movies make use of the English language, Vollywood movies use the Ewe language so do Nodrafilm movies make use of the Northern Regional languages in Ghana.
According to Adjei (2014), the dominance of "Akan" films is a direct carry-over from the Concert Party tradition where the Akan language is more or less the lingua franca, to the extent that even non-Akan actors and actresses are forced to function in the Akan medium. They indicate that in most productions, there is a longstanding tradition of poking fun at Ewes and Northerners who are projected as incompetent users of the Akan language. Indeed, they make it explicit that, films in the Twi language are far more popular than those in English simply because they are a carry-over from popular theatre, targeted at that massive constituency of patrons which includes peasants, market women, semi-literates and children for whom an indigenous language in any narrative context is closer to them linguistically.

\section{Importance of Culture in Akan Movies}

Ghana, like most countries in Africa, has taken some necessary action needed to put the creative economy at the forefront of the development process (Meyer, 2003). Indeed, it is stressed in the National Cultural Policy of Ghana (2004) that in the era of globalization and contemporary technological challenges, the people of Ghana must recognize their culture as the basis of, and the most important factor in the nation's human and material development. And accordingly requires creative and cultural industries such as the local film industry to continue to exercise a deep influence on the history, cultural values, and the nation's destiny as well as national life (National Commission on Culture, 2004).

Garritano (2008) indicates that the inexpensive, widely available and easy-to-use technology for the production and duplication of the movies have transformed movie production on the African cultural landscape. The birth of the video format in the 1990s commenced the paradigm shift in cinema in Ghana, which also has led to new trends and genres in the Ghanaian cinema (Tamakloe, 2013). This shows that the number of popular local movies produced in Ghana is becoming astounding and it is therefore important to analyse their socio-cultural impact regarding transformation and acculturation of the Ghanaian culture. Ghanaians cherish, love, practice and preserve their culture and tradition through songs, Anansescm (folktales), folklores, names and manner of dressing despite their exposure to Western culture (Wiredu, 2005).

Nevertheless, in this era of acculturation of culture through globalization of the media, limited studies can be found on the cultural 
analysis of Ghanaian films. Some studies into the aspects of Ghanaian films have focused on "Traditional costumes and their relevance as cultural symbols to film making in Ghana: Asante Case Study" (Akwetey, 2007); "Assessing Brand Ghallywood: A study of the elements that constitute and characterize the Ghanaian Film Industry" (Akrofi, 2013). Indeed, it is only Adeleke (2003) who has tasked African filmmakers to adopt genres that suit African culture.

It is becoming very difficult to understand the true significance of the Ghanaian philosophical and moral values in these films. These foreign culture inclusions in Ghanaian films contradict with the authentic indigenous Ghanaian culture and tradition which are still very much alive and cherished, valued, practiced and treasured despite western cultural infiltration (Boadou, 2011). Schultz (2012), however, posits that Nollywood films prosper by satisfying preference for material that speaks to Nigerians: expression of a point of view - the values, desires, and fears of their popular audience. Indeed, it is a truism that Nollywood films have gained very wide acceptance among the African Diasporas within the rest of the Region in Africa and African Diasporas in Europe, America, and the Asian countries as they touch on Africans experience in everyday life, communal mutuality in village festivals, traditional dancing tunes and steps, religious worships and sociocultural cooperation in works. This experience may be identical except the language use (Fayomi, 2015). Hence, it is the objective of this paper to present an intellectual discourse on misrepresentation of Ghanaian cultural elements in films that are produced using Akan (Twi) language.

More importantly, the cultural concept in this study is relevant in addressing questions on the production of African films, about how they should be constructed to make it perform better in the global market, and attempt to provide information that would correct the misrepresentation of the Ghanaian cultures in the Akan films and the Ghana film industry in general. This has become necessary, as Western scholars using Western mode of thinking, doing things and concerning reality have dominated the production, reproduction and dissemination of knowledge in Africa.

\section{Methodology}

The qualitative research method was adopted to enable the researchers study the social and cultural phenomena of Akan people as depicted in Akan films which required ethnographic interpretation. This approach enabled the researchers to gain insight into the people's attitudes, behaviours, value systems, concerns, motivations, aspirations, culture or lifestyles as attached to proverbs and symbols. The study employed descriptive technique, based on content analysis of their cultural elements specified in this study. Primary data were collected from the Akan video films in the form of observation guide in obtaining information on Akan proverbs and wise-saying, moral conducts, foreign cultures and misrepresentation of Ghanaian cultural elements portrayed in Kumawood movies. Sampling was based on some key elements that the researchers believe contribute to the popularity of Ghanaian films (the subject matter of the films, the language and cultural aspect of the films). The following six movies were selected for the study: Menko M'Abusua (The Family I Have), Time Changes, Ama Ghana, Okomfo Anokye, the Bearer and Praba. The instrument used in collecting the video data was a designed film observation guide. In line with the study objectives, the data collection guide was designed into two sections namely, foreign cultural elements, and culture misrepresentations. Indeed, the instrument guided the researchers as to what scenes, words, mode of dressing, attitudes, performances, etc. to critically observe and note in the selected films during the watching.

The data collections were undertaken by seven assistants who were well versed in Akan traditions. These people were selected by virtue of their rich knowledge and familiarity in Akan culture. The video data collection involved multiple viewings of the selected films and playing back of scenes considered important for clarifications.

The first viewing of each film was geared towards enjoying the film without worrying about the argument to be eventually cultivated and to establish familiarity with the video data (Jewitt, 2012). However, it was during the second viewing that focuses were given to the interesting elements of the films that the study highlighted to explore. Nevertheless, it became irrelevant to watch the film after the second watching since the panel could recollect most of the events and scenes observed for documentation and analysis. It was during the second viewing that the relevant video data were transcribed. The video data transcribed from text to words were analysed with Qualitative Content Analysis techniques to offer a framework to 
account for transcripts as artifacts, treating them as empirical material. The anonymity of the video data was ensured through the use of coded identification.

\section{Findings}

The findings, which were based on the watching of six sampled Kumawood movies (video CDs), present the critical analysis of distortion of Ghanaian cultural elements in Akan language films.

\section{Synopsis of the Six Sampled Movies}

\section{Menko M'abusua (The Family I Have)}

This movie is set in the present-days in a Ghanaian Akan community. The movie tells the presupposed everyday stories whereby family members liaise with others to bewitch the wellto-do members of the family, bringing them from grace to grass. The narration tells of two sisters namely Benewaa and Ama Foriwaa whose main aim is to destroy their younger brothers Akosah and Nkrumah. Through witchcraft, they disable Akosah, make him jobless and mentally deranged. Through this same diabolic and mischievous behaviour of spirituality, they try to prevent Mina, Nkrumah's wife, from getting pregnant. They vilify anyone who tries to help these brothers and eventually prevent any good from coming their brothers' way. Through witchcraft they make life very unbearable for Mina, Nkrumah's wife, prior to and during their marriage. They take Nkrumah's household and saturate it with witchcraft. Through the same diabolic and mischievous behaviour of spirituality through witchcraft, they try to prevent Mina from getting pregnant, but through prayers, God blesses them with a girl child. Mina is able to sustain her husband and child with her prayers. Unfortunately, her own child is infiltrated with witchcraft by these witches and uses it against the father. How long can Mina keep praying? Will Nkrumah finally realize the spiritual problems in his family? At the end of the movie, Mina with the help of a pastor prays with Nkrumah in their family house and there is manifestation as the witches confess their evil deed and the family is released and saved.

\section{Time Changes}

This movie tells the story of two sisters, Akosua Dompo and Adwoa who were fighting over a kingship position for their sons. This is made known when the king, one day, foretells the heir apparent to his thrown in his absence that the ancestors through the king's dream have revealed that the son of Adwoa, becomes the next king when he is no more. The families are called to the palace to discuss the issue and in order for her eldest son to win. Akosua Dompo, through consultation with the god of Atwea via juju, cripples her sister's son, Nkansah and makes her daughter Noami, blind.

Akosua Dompo's son and another person are set on the throne and are both rejected by the gods. It is here that the crown leaves the throne by itself and finds Nkansah in the forest. Nkansah, Naomi and Adwoa are transported to the village square where the chieftaincy activity is happening. All of the sudden, Nkansah could stand and walk, Naomi could see again. Nkansah is made king and Akosua Dompo goes blind; the truth comes to light through the confession of her deeds, bringing about poetic justice. Everyone gets to know the evil machinations of Akosua Dompo.

\section{Ama Ghana}

The movie tells the story of Kaakaku and his wife Araba, a poor couple whose main aim or motive is to find a very wealthy man to give their beautiful daughter, Ewura Ama's hand in marriage. This couple extorts money from would-be suitors and people who come to seek her hand in marriage.

Ewura Ama, who happens to be a very beautiful girl in her prime, faces a lot of pressure from her peers and parents alike to marry a rich man per her parents' wish. Whilst she in turn battles them, she also feels that age is gradually catching up on her. After throwing away various suitors, her parents finally find her a rich man to marry. Despite the good fortunes of the man, he is unable to sexually satisfy Ewura Ama to consummate their union because he is impotent. Under the influence of her two promiscuous friends, Ewura Ama begins to have extra marital affairs. Ewura Ama's husband is advised to seek help from a German doctor who is a specialist in potency issues such as the one he is experiencing. He then travels to Germany for medication and comes back a full man, very potent. He goes looking for his wife to resolve all the issues in their marriage and reunite.

\section{The Bearer}

Civilization is either destroyed or made when its beliefs, traditions, norms, value systems and worldview are made or destroyed. It was in the 
era of slave trade and missionary exploration in Africa when the Europeans docked their sailing ship on the shores of gold coast to trade. History has it that, the same ship that brought guns and gun powder as well as alcohol was the same that brought the BIBLE. Two most powerful native priests, Okomfo Kyenkye and Okomfo Tuda are sent to pursue the missionaries from the Fanteland. Unknowingly to Kyenkye, Tuda had plotted to eliminate him on the expedition because the white slave traders are his allies. Tuda and his brother, Atobra, are deeply engaged in kidnapping and capturing natives as slaves and trading them off for gold and silver bars, broken mirrors, gun and gun powder, etc.

At the church of the Berch, the priests and their guards confront him. Berch sees them shoot at Kyenkye of which he takes the bullet in his stead to save him. Berch dies and Kyenkye becomes the bearer of his message, the Gospel of Christ. JkomfooKyenkye quits practicing his craft of native priesthood and turns to propagate the gospel of Christ with the use of the Holy Bible. This fuels the hatred and anger that Tuda has for him. Tuda tries all means to assassinate him so as to do away with every obstacle hindering his secret trade. Kyenkye is able to preach the word of God to the majority of the inhabitants, changing them to Christians. He can also memorize most scriptures in the bible. When he is captured as a slave by his own people, his bible is destroyed. He is beaten and persecuted by Tuda and his brother with the permission of the king as was done to Jesus Christ.

In a second assassination attempt, Tuda mistakenly shoots his only brother Atobra dead, instead of Kyenkye. The captive slaves break free. Kycnkye meets Tuda in a duel but spares his life. He goes to a sanctuary where he meets two white ladies who reprint the Bible via his narration. The message reaches the throne that the captured natives have broken loose and come home. Kyenkye comes back with his new Bible to preach to the authorities. The deeds of Tuda also become bare in front of the king and his elders through his confession, bringing about poetic justice.

\section{Praba (A goddess of Vengeance and Retribution)}

Fanteman is a peaceful and prosperous Akan settlement. The secret of their success lies in Praba, the goddess of vengeance and retribution, whom they all serve committedly. Adu, the warrior, throws away the image of Praba for its inability to cure his ailing daughter that led to her subsequent death. Consequently, Praba returns with vengeance on the village for the abomination of one man. The oracle, the infallible one, has spoken through the priestess that Adu must journey through the 'evil' forest to the land of the living dead to find the image of Praba which he threw away, of which he adamantly has refused.

\section{JkomfoAnokye}

This movie therefore is geared towards telling the history of the Ashanti Kingdom through Okomfo Anokye, an Ashanti fetish priest, statesman and lawgiver. A cofounder of the Ashanti Kingdom in West Africa, who helped establish its constitution, laws, and customs. His father was called Kaku Ackah and his mother, Maame Nkobe. Anokye was named after his paternal Uncle Egya-Ano who was a fetish priest. The Nzema called him Ano kye which means 'Ano Junior'. The Denkyira's later heard of his wonders and requested his aid. Through Anokye's help, the Asante people successfully defeated the people of Denkyira.

Osei Tutu, the King of the Ashanti, requests Anokye's aid. Anokye obliges and with Osei Tutu carries out an expansionist policy on their predecessors, defeating the powerful Denkyira. Okomfo Anokye brings the golden stool from the sky and gives it to the Ashanti people. He also puts a sword on the ground as a symbol of unity amongst the people of Ashanti. Some elders plan to kill him and in the end Anokye disappears.

\section{Discussions}

\section{Misrepresentations of Akan Cultures in Akan Fillms}

The objective of the study sought to assess whether scenes in the films distort Ghanaian cultures, especially Akan cultural values, norms, beliefs, symbols and characteristics. Semali and Asino (2013) posited that global media and the non-Africans who drive projects of films of cultural heritage have distorted the reality of Africa. In the same vein, the current study reveals some number of scenes misrepresenting Akan cultures of Ghana in films directed by Ghanaians. It was obvious in the movie Okomfo Anokye that, Anokye's parents disrupted a council meeting by just budging in unwarrantedly to the palace while the council was in a meeting; In the Menko M'abusua and Time Changes movies the fetish priestess and elders spoke to kings without recognizing the presence of the linguist who is the mouthpiece of the stool; the priest and priestess also walked 
and spoke without acolytes. The elders of the land, who happened to be the custodians of the land, tied their cloths in knots on their right shoulders instead of packing them on their left shoulders. Those scenes contradict with courtesies of the Akan tradition as well as the palace norms and practices. Indeed, it obviously depicts the lack of order and a sign of gross disrespect to the traditional stool (which is the symbol of the office of the king), customs and traditions of the Asante kingdom as a whole. However, these victims of the traditional courtesies and formalities were not penalized but were set free. A traditional elder had an unkempt hair (dreadlocks) whilst, a king's palace was represented as living room with sofas and few pieces of Kente cloth hung as the backdrop; whilst the enstoolment processes of a king is done in secrecy and later the chosen king is presented to the public. In the movie Time Changes, the enstoolment of the king (Nkansah) was done in public. These phenomena may explain why many Ghanaian audiences are concerned about how the upsurge of local movies misrepresent the Ghanaian and for that matter the "Akan" culture as a whole. Surprisingly, Okomfo Anokye and Time Changes were films supposed to be purely based on the Akan traditions and historical events; which were ultimately expected to show authenticity and originality of these cultures, but rather misrepresent the symbolism and cultural values of the people. In the Akan political setup and culture, elders including the linguist, when addressing the king, ought to lower their cloths to their lower waist; but in contrast, this was not practiced by all people who spoke to the kings in the Menko M'abusua and the Okomfo Anokye films.

Moreover, in the Akan political setting, an Akan leader, royal or council of elder's traditional hair style is the one cut down and known as Dansinkran or any befitting hair style, but contrary to what was in Time Changes, a traditional elder had an unkempt hair (dreadlocks). Indeed, the name of that elder affectionately was Agya Mpesempese (which literally means an elder with unkempt hair) as an evidence. In the Akan tradition, a bastard does not qualify to be an heir to a throne; however, a bastard was also among the nominees for the kingship position although he was later rejected by the gods.

In the Akan political system, the linguist (Jkyeame) is the spokesman of the chief and nobody speaks to the chief except to and through him. Nevertheless, in Okomfo Anokye, elders did speak to the kings directly and even without permission from their linguists. In another instance, the meeting of the priestess by Anokye's parents, the priest spoke without an acolyte and also directly to the king. These findings support the position of Garritano (2008) that the makers of popular movies have not been principally concerned with authenticity, cultural revival, or cultural preservation. This development regarding misrepresentations of traditional culture validates Bego's (2010) position that "the present generation of filmmakers lacks the competence and awareness to develop the right content for their movies".

As indicated by Adjei (2014), even non-Akan actors and actresses as well as filmmakers are forced to function in the Akan medium. It is nevertheless a surprise that Akan films are wrongly stating Akan proverbs because some of the casts or characters are not well versed in the Twi language. This may be accounting for some distortions in these proverbs as found in Menko

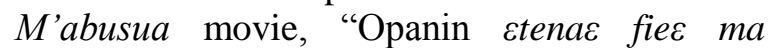
nkwadaa Ewe nanka a, ye bu no nankawefor number one". In truism, the proverb should been stated as: $\mathrm{S} \varepsilon$ opanin tena fie ema nkwadaa we nanka nayerekan nanka wefor $a$, ska ho bi. This proverb literally means: should an elder sit unconcerned and allow children devour snake, when recognizing the favourites of snake meat, he is regarded amongst the devourers. The number one as used in the proverb is as an emphasis. Indeed, in its correct usage, the 'number one' should have been "oka ho bi" (meaning 'he is among'). It is clear that there is a corruption of the Akan language with that of the English language, which is in inappropriate in terms of preserving the Ghanaian cultural heritage. In another assertion, it was noted that an Akan proverb was wrongfully stated thus: $S \varepsilon$ Edin bonii antumi woa, etete wontoma was wrongfully stated. In the correct sense it should have been stated as "Scnimoantumiwo a Etetewontoma. The literal meaning suggests that: If your name is continuously and controversially mentioned in an instance, its implication comes with its resultant effect on you. In the film, the proverb was used to point out a character's bad behaviour and attitudes.

Another proverb wrongly used is: Dee akonwa ese no na odie. This should have been 'Decadecwo no na odie'. Thus: It is only the people who befits the throne that are enstooled as kings. Another interesting finding on the Akan proverbs in the films was on their 
presentation of matters of individual responsibility. In Praba, the linguist said that, Daasebre, ye se obi nnom aduro mma syarefo which literally means 'Medicines are not taken on behalf of the sick'. The distortion of the Akan proverbs is inimical to the preservation of the original rich philosophical, educational, socio-cultural and moral values for posterity (Yankah, 2012; Boaduo, 2012). It is important to state that Ghanaian filmmakers should learn how to present the Akan proverbs in their original states, understand the socio-cultural and philosophical significance of these proverbs; and how they are created and used in various contexts (Yankah, 2012).

In Time Changes, there was a scene of wrong representation of customs and traditions in relation to enstoolment of the king. It was obvious in the movie that the enstoolment process of the king was done in public. Customarily, a king's enstoolment is not a public affair. Without a doubt, a nominated candidate is placed under custody for grooming and training for some weeks by the elders well versed in the traditions of the state, where he learns more traditions and other cultural norms. It can be inferred from the findings that Akan films highly distort the traditional political practices. This means that such films have been used to subjugate the Akan and Ghanaian culture rather than to persuade, propagate, entertain, instruct and educate the audience on the sociopolitical as well as the economic needs of the audience (Akashoro, 2010).

There was a scene which contradicts with the Ghanaian hospitality manners. In Ama Ghana for instance, Uncle Odum and his family visit Kaakaku and his wife Araba, who refuses to offer them seats and water as tradition demands. In Ghana, especially among the Akans, the first thing a person does when he gets a visitor is to offer him/her a seat, followed by drinking water before asking of missions. Also, in Ama Ghana, a disrespectful scene is observed when Awura Ama gives her underwear, thus panties and brassieres, to a man to wash, which is a taboo in Akan culture. The man who happens to be the security man washes these underwear, stretches them open, smells and fraternizes with them.

\section{Influence of Western culture in Akan language films}

The influence of Western culture in Akan language films has had both direct and indirect devastating toll on the culture of Ghanaians. Films are a form of media that spread very fast every aspects of a people's culture. Regrettably, Ghanaian, and for that matter African ways of doing things are no longer in the public domain. Colonialism, being a powerful force of Western culture, has indeed robbed the continent of opportunities: opportunities of self-development, of self-government, and of self-styled technological development pace so much so that when youths engage with the media they crave for Western norms and values.

The unstoppable wave of globalisation in Africa is a result of Western interference on the pace and tempo of cultural growth and civilisation in the continent. Though colonialism is now a thing of the past, Africa remains subjugated and dominated by the commodities and cultures of the colonial powers. It is lamentable that the Western culture continues to thrive and outgrow African cultural heritage. A critical review of most "Akan" films show an influx of Western popular culture such as romantic scenes in public, stalking, seduction and performance of sexy erotic dances as well as occultism and the use of vulgar words. Additionally, Western mode of dressing, food, architecture, arts and craft, music and dance have dominated scenes in these movies.

\section{Conclusions}

Cultural elements as well as practices strongly and adequately showcased in local films or movies project the fact that the film industry exercises a deep influence on the history, cultural values and a nation's destiny as well as the national life presenting its positive image to the rest of the world. Nevertheless, most Kumawood movies produced in Ghana underscore the reality that they misrepresent Akan cultural values, beliefs, symbols and characteristics, which misinform foreign audience about the true and rich Akan cultural heritage.

As part of Kumawood movies' contribution to the projection of Ghanaian culture and restoration of Akan cultural values in the media, these films should sufficiently capture and begin to promote ideas that reinforce quality of life, national pride and consciousness; motivate and stimulate creativity. All this should be inspired by our traditions and values, such as respect for humanity, justice, constituted authority, the dignity of labour as well as national developmental aspirations and needs.

The Akan film industry, as a matter of urgency, must shed its large baggage of mimicry of Western popular culture such as romance and 
petting scenes (stalking; seduction and performance of sexy erotic dances as well as reoccurrences of witchcraft and occultism); and insults in order to achieve high artistic standards through training and capital injection. To be able to well orchestrate and authentically showcase the traditional customs and avoid cultural misrepresentations in Akan films, there is the need for extensive research to obtain reliable information from traditional chiefs and queens, linguists and members of society who are well knowledgeable in the customs, traditions and histories of the people. Finally, indigenous settings where culture remains less adulterated should be largely utilized when these movies are being produced in order to preserve the rich Ghanaian cultural heritage.

\section{REFERENCES}

[1] Adeleke, A. D. (2003). Culture, Art and Film in an African Society: An Evaluation. Nordic Journal of African Studies 12(1): 49-56 (2003)

[2] Adjei, M. (2014). The video-movie flourish in Ghana: Evolution and the search for identity. Research on Humanities and Social Sciences ISSN (Paper) 2224-5766 ISSN (Online) 22250484 (Online) Vol.4, No.17, 201461

[3] Akashoro, G. O. (2010).The African filmmaker and content of African films: a study of the perspectives of the Nigerian film audience. Global Media Journal African Edition 2010. Vol. 4 (1) doi: 10.5789/4-1-14.

[4] Amayo, U. P. and Uzo, P and Ernest-Samuel, C. G. (2012). E-Culture and African video films in a globalized world: Amayo Uzo Philip's Akwaeke Na Odum and Sacred Tradition as Paradigms. UJAH: Unizik Journal of Arts and Humanities, Vol. 13 No 2, 2012.

[5] Anderson, G. (2013). Religion and Morality in Ghana: A Reflection. Global Journal of Arts Humanities and Social Sciences Vol.1, No.3, pp.162-170, September 2013

[6] Anyanwu, U. D. (2011). For the sake of history, culture and development. Inaugural Lecture Series 4. Owerri: IMSU Press, 2011.

[7] Boaduo, N, A. P (2011). Philosophical Discourse by the Asante of Ghana: Mythological Symbolic Analysis. The Journal of Pan-African Studies, vol.4, no.3.
[8] Boaduo. A. N. (2012). Epistemology of Proverbs and Idioms of the Asante Ethnic Group of Ghana for Introspection. The Journal of Pan African Studies, vol.5, no.3, June 2012

[9] Fayomi, O. O. (2015). Transnational and Integrative Cultural Roles of Nollywood Entertainment Media in West Africa: The Case Study of Benin Republic and Ghana

[10] Garritano, C. (2008). African video movies and global desires: A Ghanaian history. Ohio University Research in International Studies Africa Series No. 91, Athens

[11] Gedzi, V. Z. (2014). The Asante of Ghana. International Journal of African Society Cultures and Traditions Vol.2, No.3, pp.20-26, December 2014. ISSN 2056-578X (Online)

[12] Ghana Statistical Service (2012). 2010 Population and Housing Census, Accra, Sakoa Press Limited

[13] Jewitt, C. (2012). An Introduction to Using Video for Research. National Centre for Research Methods Working Paper 03/12.

[14] Kwanashie, M., Aremu, J. A., Okoi, K. and Oladukun, K (2009). Research into the Impact of Arts, Culture and Creative Industries on Africa's Economy. Agoralumiere International and with the support of the Federal Ministry of Commerce and Industry 2009.

[15] Meyer, B. (2003). Ghanaian popular cinema and the magic in and of film. In Meyer, B \& Pels, P. (Eds.), Magic and Modernity: Interfaces of Revelation and Concealment, Stanford University Press

[16] Ryan, M. D. (2009). Whither culture? Australian horror films and the limitations of cultural policy. Media International Australia incorporating Culture and Policy (No 133). pp. 43-55.

[17] Schultz, M.F. (2012). The Nigerian film industry and lessons regarding cultural diversity from the home-market effects model of international trade in films. M2922 - PAGER 9780857931337 PRINT.

[18] Tamakloe, A. (2013). Social representation in Ghanaian cinema. Thesis: University of Ghana http://ugspace.ug.edu.gh 11

[19] Yamoah, M. (2014). The New Wave in Ghana's Video Film Industry: Exploring the Kumawood Model. International Journal of ICT and Management. Vol. II Issue - 2 .

Citation: Kquofi, Steve, and Godfred Kojo Croffie. "Aberration of Cultures: A Study of Distortion of Akan Cultures in Kumawood Movies in Ghana". International Journal of Research in Humanities And Social Studies, vol 4, no. 5, 2017, pp. 8-16.

Copyright: (C) 2017 Kquofi, Steve. This is an open-access article distributed under the terms of the Creative Commons Attribution License, which permits unrestricted use, distribution, and reproduction in any medium, provided the original author and source are credited. 